\title{
Globalizations
}

\section{The role of emotions during the Arab Spring in Tunisia and Egypt in light of repertoires}

\section{Efser Rana Coşkun}

To cite this article: Efser Rana Coșkun (2019) The role of emotions during the Arab Spring in Tunisia and Egypt in light of repertoires, Globalizations, 16:7, 1198-1214, DOI: 10.1080/14747731.2019.1578017

To link to this article: https://doi.org/10.1080/14747731.2019.1578017

曲 Published online: 15 Feb 2019.

Submit your article to this journal $\pi$

Џlll Article views: 1242

Q View related articles $\sqsubset$

View Crossmark data \lceil 


\title{
The role of emotions during the Arab Spring in Tunisia and Egypt in light of repertoires
}

\author{
Efser Rana Coşkun \\ Bilkent University, Ankara, Turkey
}

\begin{abstract}
This article examines the role of emotions during the Arab Spring in Tunisia and Egypt in the context of collective level emotions in mobilizations. Emotions are understood as a catalyst whose mechanism of action is performed through repertories. This article seeks to answer how emotions, having a triggering role, are performed through repertoires while accelerating mobilization against authoritarian orders, creating the intersection of individual and collective level emotions in public spheres of Tunisia and Egypt, and thus affecting the transnational diffusion of emotions. The significant reason to address emotions is to explain what stimulated the Arab Spring and how it spread over the region starting from Tunisia and Egypt. This article synthesizes two literatures: International Relations (IR) and social movements studies in light of emotions and components of repertoires which are as follows: collective action, collective identity, symbolic politics, network society and information politics.
\end{abstract}

\section{KEYWORDS}

Emotions; Arab Spring; repertoires; collective level emotions; social movements

\section{Introduction}

What is the role of emotions during the uprisings? Why should we analyse emotions in the Arab Spring? These are essential and stimulating questions to elaborate a different perspective for the investigation of the unexplored features of the Arab Spring. Emotions play a significant role in world politics and the discipline of International Relations (IR). In this article, emotions are defined as interactive reactions that are mutually formed by individual level and collective level experiences and expressions. In the context of the Arab Spring, within transnational protests, these emotions or alternatively interactive reactions mainly derived from reactions regarding what people experienced under oppressive political orders in Tunisia and Egypt leading them to express their responses out-loud in public spaces. Even though emotions are private, intimate, and subjectively vivid, they can be described as trans-subjective and contagious patterns of the human responsiveness, as Ross $(2014$, pp. 15, 22) contends. Therefore, these interactive reactions were mutually reinforced through people's experiences and expressions regarding moral shocks under oppressive orders fuelled by injustice and despotism. This created the intersection of individual and collective level emotions in public spheres of Egypt and Tunisia, because emotions are 'part of the social tissue connecting individuals', as Ross (2014, p. 33) identifies. As a result, emotions can be understood as a catalyst whose mechanism of action is expressed and performed through repertoires. In particular, this article seeks to answer how emotions during the Arab Spring, having a triggering role, are 
performed through components of repertoires that include a wide array of the instruments of performance of emotions while accelerating mobilization against authoritarian orders, creating the intersection of individual and collective level emotions in public spheres of Tunisia and Egypt, and thus affecting the transnational diffusion of emotions. The value of the inclusion of emotions is to explain what stimulated the Arab Spring and how it spread over the region starting from Tunisia and Egypt. The first section will unpack the background and reflections of emotions during the Arab Spring in Tunisia and Egypt. To reveal 'emotion as a catalyst' whose mechanism of action performed by repertoires, the second section will assess components of repertoires that refer to means that groups in Tunisia and Egypt used for making claims to perform and to diffuse their emotions nationally and transnationally to topple authoritarian leaders (Tilly, 1986, p. 4) which are as follows; collective action, collective identity, symbolic politics, network society and information politics. In particular, in the age of globalization, through the expansion of transnational public sphere as Moghadam (2013, p. 28) argues, social networking technologies and transnational slogans under collective identity facilitated to diffuse emotions and to catalyse social interactions (Ross, 2014, p. 33).

The most important question raised by Bially Mattern (2011) is how one, who is interested in the role of emotions in world politics, begins. As the core contention of the article is to understand emotions as catalyst that are recognized as interactive reactions as a result of the intersection between individual and collective emotions, it would be beneficial to overview how emotions are studied in various works in order to investigate what those studies neglect in terms of the linkage between emotions in IR and transnational protests, and how it can be remedied through integrating social movements literature.

Considering multiple ways to analyse emotions in relation to different dynamics, since the object of the present study is to focus on emotion in IR and its role as a catalyst through various components of repertoires in the Arab Spring, this article aims to assess the role of collective-level emotions as embodied expressions or performances during mobilizations in Tunisia and Egypt. Towards this end, apart from different frameworks of emotions such as cognition oriented works or accounts taking emotions as non-reflective bodily sensations in light of affect (Clore \& Huntsinger, 2009; Frijda, 1986; Hutto, 2012; Massumi, 2002; Nussbaum, 2001; Thrift, 2004), what 'emotional turn' in IR overlooks is emotions' role in transnational protests or movements like the Arab Spring. These issues are generally ignored in the literature concentrating on emotions and state behaviour (Eznack, 2011, 2013; Hall, 2016; Koschut, 2014) or emotions in elite-decision making (Crawford, 2000, 2014; Mercer, 2006, 2010, 2014; Pace \& Bilgiç, 2017).

Considering that 'emotions in world politics' is an emerging field in the discipline of IR with open questions and gaps as Koschut (2017b, p. 1) contends, recent scholarly works paved the way for new analyses of emotions (Bially Mattern, 2011; Bleiker \& Hutchison, 2008; Crawford, 2000; Fattah \& Fierke, 2009; Hutchison, 2016; Hutchison \& Bleiker, 2014; Koschut, 2017a, 2017b; Koschut et al., 2017; Solomon, 2018). It is worth to note that Crawford (2000), Mercer (2006, 2010), Bleiker and Hutchison (2008), Bially Mattern (2011) were among the first regarding conceptualization of emotions in world politics. Earlier scholarly works have differed from recent analyses of emotions in IR that regarded emotions in opposition to reason and rationality (De Sousa, 1987; Elster, 1999). Since the 1970s emotion and reason have become intertwined in foreign policy analyses regarding the process of decision-making (Hutchison \& Bleiker, 2014, p. 495). Examples of studies can be found in works of Hill (2003), Jervis, Lebow, and Stein (1985) arguing that 'emotions were seen as interferences with or deviations from rationality' (Hutchison \& Bleiker, 2014). Similarly, emotions are accounted as epiphenomenal meaning seen as a consequence and rarely as a cause (Hardin, 1995; Mercer, 2006, p. 290). In light of what Elster asserts 'emotions provide a meaning 
and sense of direction to life, but they also prevent us from going steadily in that direction (1989, p. 70), the clash between emotions and rationality was a key argument taking emotion as consequential, albeit as a source of misperception and mistake explaining deviation from a rational baseline (Elster, 1999; Jervis, 1976; Larson, 1985; Mercer, 2006, p. 291). The other conceptualization is 'emotion as strategy' as in the work of Hirshleifer (1993) understanding emotion as both rational and strategic which echoes Mercer's works analysing emotions as substrate' of the thought-based constructs rationality and belief (Mercer, 2006, p. 29, 2010, p. 11).

Neta Crawford's works concentrate on the dichotomy of emotion and rationality through explaining the relation between passions of IR and theories of security and international politics (Crawford, 2000). The impacts of emotions on constructing political institutions within discursive contexts were analysed regarding the elite decision making processes that merely concentrated on emotions at the institutional level (Crawford, 2014; Pace \& Bilgiç, 2017). However, given the importance of social interactions, Bially Mattern (2011) defines emotions differently as 'the embodied experiences of concrete persons but they are not actually the properties of those persons' (p. 63). This purports that experiences practiced by individuals derive from interactions between various agencies and structures (Bially Mattern, 2011, p. 63). In a similar vein, Hutchison (2016, p. 16) understands emotions as either practices or performances that are consistent with a conscious expression of a feeling in a discursive context. Even though emotions are individual performances, they are formed within particular social and political environments (Hutchison \& Bleiker, 2014, p. 504). While different conceptualizations of emotions are expressed, many scholars generally agree that: 'individual emotions can be collectivized among members of a group through the participation in social discourses and cultural practices' in Koschut's words (Koschut, 2017a, p. 7; Bially Mattern, 2011; Crawford, 2014; Hutchison, 2016; Hutchison \& Bleiker, 2014). However, in the aforementioned works in IR with regard to the emotional turn, social movements literature should be engaged with IR literature in terms of components of repertoires in order to assess emotions' role as a catalyst formed as interactive reactions, demonstrating how those interactions, and hence emotions were performed at the transnational level during the Arab Spring.

In IR and social movements studies, the Arab Spring, including the expansion of the revolts, has been studied through various perspectives. These perspectives are as follows; the role of social media (Axford, 2011; Dajani, 2012; Khondker, 2011; Lynch, 2014; Tufekci \& Wilson, 2012), the analysis about the role of regional and international geopolitics with a particular focus on political and economic grievances (Hollis, 2012; Ryan, 2014; Solomon 2018) and rational frameworks of diffusion and mobilization of revolts in the Arab region inspired by various models of mobilizations in social movements studies including the general role of emotions in different theoretical perspectives looking at empirical examples (Aminzade \& McAdam, 2001; Calhoun, 2001; Goodwin, Jasper, \& Polletta, 2000, 2001, 2004; Goodwin \& Pfaff, 2001; Hale, 2013; Jasper, 1998; Kemper, 2001; McAdam, 1982; Patel, Valerie, \& Sharon, 2014; Tilly, 1978; Walsh, 1981; Weyland, 2012). Various novel analyses have been assessed on insurrectional politics, cosmopolitan aspects of the Arab Spring, the concept of 'the Global Street', the impact of globalization on movements in the Arab region, women's role in the Arab Spring, and microfoundational analysis of emotions from a neurosciences perspective in the Arab Spring (Agathangelou \& Soguk, 2011; Carreon \& Moghadam, 2015; Moghadam, 2013; Pearlman, 2013; Sassen, 2011; Soguk, 2015). In these accounts, emotions remain to be explored with respect to its diffusion within uprisings and catalytic role at a transnational level in the Arab Spring in light of various components of repertories. To put it alternatively, these studies do not particularly focus on collective-level effects of emotions in movements as in the Arab Spring (Solomon, 2018, p. 946). 'Waves of emotion' (Lasas, 2011) or 'affective waves' (Hall \& Ross, 2015, p. 848) 
particularly in Tunisia and Egypt led to 'the rapid and massive diffusion into a regional tidal wave' (Lynch, 2012, p. 68).

Emotion comes from the Latin verb emovere that means 'to move out' or 'to move' (Ahmed, 2004, p. 11). Regarding the centrality of emotions throughout the uprisings of the Arab Spring, emotions designated the power of people that are inherently embedded in repertoires of uprisings. In order to understand where emotions are located, it is required to unpack traditional thinking on the Arab Spring. Recent literatures on the Arab Spring and grassroots uprisings ousting the authoritarian orders in Tunisia and Egypt focus on the profound role of streets, common spaces, and major squares (Abdalla, 2016; Bayat, 2013; Bellin, 2012; Huber \& Kamel, 2015; Pace \& Cavatorta, 2012; Pearlman, 2013; Sadiki, 2015; Sassen, 2011). Despite offering rich insights, these studies overlook the intersection of individual-level emotions and collective-level emotions constituting mass emotional spaces throughout the Arab Spring erupting in Tunisia and then Egypt.

\section{The background of emotions in the Arab Spring: Tunisia and Egypt}

The significant question to ask is what pushed people to revolt against authoritarian orders. The uprisings across the Middle East and North Africa started on the 17 December 2010 erupting in Tunisia. As a consequence of 26-year-old street vendor Mohamed Bouazizi setting himself on fire - which became the symbol of Jasmine Revolution - the uprisings expanded to Egypt, Libya, Yemen and other countries as well. Through Bouzazizi's self-immolation 'the barrier of fear has broken' - inkasar hajez el khawf (Pearlman, 2013, p. 388). His sister expressed the death of Bouzazizi as a 'rebellion against insult' that was motivated by 'oppression, despotism and injustice' (Pearlman, 2013). Bouazizi became a symbol of freedom, dignity, and justice for people who fought for transformation as well as a stimulus for others that triggered righteous anger (Lim, 2013, p. 1; Pearlman, 2013). Considering it either self-immolation or 'self-sacrifice', Bouazizi led to 'act of speech' in which the suffering body was communicating the injustice and anger experienced by the majority of the society (Fierke, 2013, p. 37). The important point is that 'selfsacrifice communicates to an audience and produces consequential effects' (Fierke, 2013, p. 37). In this regard, anger and indignation emerged not as an incidental characteristic, but as the motivation and explanation of protest (Jasper, 1998, pp. 397-398). After Bouazizi, hope was triggered which paved the way for the expansion of interactive reactions leading to a common goal through a process of 'rhythmic entrainment', as Collins points out (2004, p. 48). People throughout the uprisings in Tunisia and Egypt focused on a particular goal through a decisive action forming upon their behaviours expressed in 'al-Sha'b yurid isqat al-nizam - the people want to bring down the regime' (Al Jazeera, 2011).

As a consequence of mass demonstrations, Ben Ali's regime was overthrown on 14 December 2011. The resignation of Ben Ali thus led people to reconsider calculations through hope not only in Tunisia but also in the region regarding the probability of overthrowing leaders of state through uprisings (Pearlman, 2013, p. 389). In essence there are two major historical incidents which led to the 2010-2011 Tunisian popular upsurges: lasting labour movements and established grassroots contentious activism integrated with various emotions such as anger, fear, indignation and eventually, hope (Della Porta, Andretta, Mosca, \& Reiter, 2006, p. 103). The popular movements of Tunisia in 2011 were not the first massive ones. Throughout 2008, in Gafsa and Redeyef, Tunisia witnessed mass uprisings led by miners. The Gafsa uprising was the very first visible expression of indignation through labour (Alexander, 2011). As indicated earlier, fear was broken in Tunisia, as expressed by an activist 'after today, no more fear' (Anis, 2012). 
Through the spread of hope from Tunisia to Egypt through the elimination of fear, the resistance of Egyptians filled with courage began. Egyptians were 'empowered by Tunisia's uprising' as Solomon points out (2018, p. 947). The beginning of the Egyptian movements was on the 25 January 2011, in Tahrir Square, Cairo with people taking to the streets to topple the Mubarak regime. As Bayat (2013, p. 184) emphasizes that, the streets and squares were physical places where collective dissent can be both expressed and produced through particular emotions formed around the spatiality of streets through expanding protests. Various parts of Egyptian society, in spite of class or geographical differences, assembled to voice their demands and emotions regarding their rights and liberties that were repressed under Mubarak. The momentum of events travelled quickly and easily across borders through a Pan-Arabist perspective focused on change in the domestic sphere (Lynch, 2012, p. 69; Solomon, 2018).

Similar to Tunisian labour unrest, the Mahalla labour uprisings were another historical origins of the 2011 Arab Spring movements in Egypt. Additionally, subsequent to labour upsurges, the other major incident which was the emotional stimulus of the contentious movements in Egypt was the death of Khaled Saeed, a 28-year-old man, killed by the police in 2010. This incident precipitated the major movements and emotions in particular - anger - to oust Mubarak in order to end police brutality and government abuses (Preston, 2011). Furthermore, through the emotional stimulus which was Khaled Saeed's death, the positive atmosphere formed around joy and hope in Tunisia pushed Egyptians to revolt against Mubarak. For example, one Egyptian woman clearly expresses solidarity based upon hope not only with Egyptians but also with Tunisian people in 'We want to see change just like in Tunisia' (Siddique, Paul, \& Adam, 2011). As a consequence of the diffusion of emotions in the region and the rise of thousands of voices in Tahrir, on the 11 February 2011 Mubarak was deposed. This was followed by an election held on 28 November 2011.

The major common point of Egyptian and Tunisian revolts is the prominence of death acting as the shock triggering an emotional catalyst to make people revolt against authoritarian orders. This was exemplified by the shocks felt after Bouazizi's self-immolation and Khaled Saeed's violent death at the hands of the police. Building on the labour uprisings, these incidents were the last straw for Tunisians and Egyptians clearly addressed in Egyptian activist's saying: 'I would rather die in Tahrir than have you govern me and live in humiliation' (Khalil, 2011). With regard to the death of Bouzazizi and Saeed, Tarrow (1998, p. 36) states that particularly violent death

has the power to trigger violent emotions and brings people together with life in common but their grief and their solidarity (...) in repressive systems that ban lawful assembly, funeral processions are of the only occasions on which protests can begin.

Tarrow (1998) highlights the prominence of violent death and anger to trigger mass mobilization centred upon collective emotions, collective identity and solidarity to revolt against authoritarian government abuses. In other words, the primary goal of transnational social movements across the Arab World was to replace the dominant existing belief systems and status quo with an alternative belief system of values supported by mass mobilization and collective action (Gamson in Lim, 2013, p. 5).

To sum up, the diffusion of social and emotional impulses to overthrow autocratic rule, prevalent injustice and the great increase in corruption and unemployment explicitly spread from Tunisia and Egypt as bellwether countries triggering contentious uprisings to other countries of the Arab World (Freedom House, 2013). In the face of indignation, anger and fear as well as the outburst of emotions that were catalytic mechanisms, people in Tunisia and Egypt succeeded in the breakdown of the regimes which was the main slogan at the beginning of uprisings. Consequently, aside from other 
countries in the region, Tunisia and Egypt demonstrated 'how the Arabs turned shame into liberty' (Ajami, 2011).

\section{Reflections of emotions in the Arab Spring: Tunisia and Egypt}

As an integral part of social actions and world politics, emotions enter every stage of protests and uprisings that can be titled as 'emotional turn' as Hutchison and Bleiker contend (Crawford, 2014; Goodwin et al., 2000; Jasper, 1998, p. 404; Hutchison \& Bleiker, 2014; Mercer, 2014). In this regard, the crucial question raised by Hutchison and Bleiker is 'how do individual emotions become collective and political?'. The answer can be derived from individuals' emotions that start to circulate in political spaces such as squares and streets in Tunisia and Egypt. Therefore, the circulation of emotions shaped collective identities emerged from Bourguiba and Tahrir squares as well as many streets and public places (Fierke, 2013). As a result, individual and collective emotions have linked to each other in collective identity construction processes in Tunisia and Egypt (Hutchison \& Bleiker, 2014, p. 505).

The three-level process in terms of the intersection of individual emotions with collective emotions of the Arab Spring reveals the intertwined relationships amongst emotions, expressions of emotions and construction of collective emotions in Tunisia and Egypt. As addressed above, through major shocks under oppressive orders fuelled by injustice and despotism after the death of Bouzazizi and Khalid Saeed, the first level is the rise of negative emotions which are anger, indignation and fear that lead individuals to join the uprisings in Egypt and Tunisia (Jasper, 1998). The Egyptian activist stated that 'anger is the primary producer of the power that every oppressed person lacks (...) anger brings the oppressed together to discover that they are capable of repudiating injustice' (Pearlman, 2013). Following Bouzazizi's self-immolation, rather than sadness, through slogans, symbols, and social media, anger emerged and blaming injustice inclined them to protest (Pearlman, 2013, p. 396). Anger, indignation and fear became the willingness to fight, because negative emotions are powerful, which stimulate mobilizations as in the Arab Spring as well as the emergence of positive emotions, particularly hope and joy (Jasper, 1998, p. 414).

In the second level, negative emotions were represented and then transformed into positive emotions through the circulation of collective emotions that spurred solidarity and collective identities. Essentially, hope was a major catalyst that drove uprisings in Tunisia and Egypt. As Ajami (2011) highlights that the revolution was waiting to happen when a street vendor - Bouzazizi set himself on fire without the frustration that pushed the old order over the brink. The barrier of fear was overcome within societies, therefore, hope turns into the key positive emotion that impulses solidarity amongst collective emotions because hope 'manages fear and inspires action which in turn produces more hope' (Kleres \& Wettergren, 2017, p. 508). Tunisians gave Egyptians hope (Pearlman, 2013, p. 398) in revealing the 'unthinkable truth' that was to overthrow the authoritarian leader, 'unblocked something in their psyches' (Khalil, 2011). This was clear from the statement of a veteran Egyptian statesman Amr Moussa, 'people will no longer accept to be marginalized and pressurized like this' (El-Shobaki, 2011).

Thanks to growing solidarity, loyalties to certain symbols including slogans and narratives, public places (Jasper, 1998) mainly Tahrir, Bourguiba as well as other squares and streets were enforced. As a result, positive emotions, joy and hope, formed around solidarity and loyalty to shared identities and symbols formed around the linkage between individual and collective emotions.

In the third level, the defiance and outrage gave way to more optimism via emotional reactions constructed within the previous levels. One Egyptian activist described Tahrir as heaven that was 
'how you wanted Egypt to be' (Solomon, 2018, p. 949; Shaw, 2011). The carnival atmosphere was welcoming and shaped by joy and hope (Solomon, 2018, p. 949). With regard to the unique atmosphere: 'it was an optimistic, celebratory atmosphere' in Tahrir even before Mubarak stepped down (Guardian, 2011). This three-level process can be summarized as the revealing of intrinsic emotions leading to fear, anger and indignation in Tunisia and Egypt through moral shocks including deaths of Bouzazizi and Saeed and previous labour uprisings (Castells, 2012; Goodwin \& Jasper, 2006). These intrinsic emotions (Goodwin \& Jasper, 2006) led to the sense of achievement started in Tunisia then augmented in Egypt and to be hopeful and joyful when the heads of states were overthrown.

Hence, considering 'politics is full of emotions' (Troost, Stekelenburg, \& Klandermans, 2013, p. 186), without emotions protests are inconceivable as emotions 'give ideas, ideologies, identities and even interests their power to motivate' (Jasper, 1997, p. 127). In regard to the triggering effect of Bouazizi's self-sacrifice, it was demonstrated that self-sacrifice is not merely an individual act (Fierke, 2013, p. 38). Rather, self-sacrifice turned into a speech act bounding up Arab people in terms of cultural and historical background which was a part of emotional resonance (Fierke, 2013, p. 38). This echoes the quote by Martin Luther King demonstrating how emotions function under the times of crises; it is not enough to be angry, the supreme task is to organize and unite people so that their anger becomes a transforming force' (Troost et al., 2013, p. 186).

In particular, within the last two decades, the growing literature on emotions will enable us to delve into the Arab Spring through the analysis of emotions in-depth (Crawford, 2014; Edkins, 2003; Fierke, 2013; Hutchison \& Bleiker, 2014; Koschut et al., 2017; Ling, 2014; Linklater, 2014; Mercer, 2014). As Sara Ahmed clearly stresses, emotions are closely acquainted and bind individuals from different backgrounds to particular objects and to others (Ahmed, 2004; Hutchison \& Bleiker, 2014, p. 123). What emotions bring together is the umbrella of various individuals from diverse segments and backgrounds; on the streets and squares in Egypt and Tunisia, besides marginalized groups particularly such as the poor and the unemployed, actors who have institutional powers students, workers, women, state employees, shopkeepers - exist so as to extend their contention regarding civil liberties under authoritarian rule (Bayat, 2013, p. 184). As a result, collective emotions and collective identity have emerged.

In a nutshell, the interconnectedness of emotions and common history brings people together sharing and fighting for the same goal. This was exemplified through the Arab Spring and the cry and fight against the authoritarian regimes oppressed and hampered civil liberties and rights. To explain further, through this interconnectedness, people transformed negative emotions into positive emotions in streets and squares in terms of similar experiences so as to exchange their experiences, feelings and stories (Troost et al., 2013, p. 187). Since emotions pervade all social life including social movements through accompanying people's deepest desires, satisfactions and dissatisfactions, emotions turn into the 'glue' of solidarity (Collins, 1990, p. 28; Hall \& Ross, 2015, p. 859; Jasper, 1998, p. 398). This is consistent with how emotions turned into collective components by various feelings and stories particularly shaped by anger, indignation and fear were reflected during the Arab Spring to transform the regime for an effective political participation and to gain civil liberties.

Hence, with respect to spaces including streets and squares, I articulate that they were transformed into 'emotional spaces'. An emotional space can be defined as 'repositories of reactions, experiences and expressions of an assemblage' in a transnational protest. Within the Arab Spring, streets and public squares became emotional spaces where emotions mutually interact amongst an assemblage through slogans, collective action and collective identity in order to trigger and channel action. This paves the way for the intersection of individual level and collective level experiences and expressions at emotional spaces. To put it alternatively, emotional spaces including streets and 
public squares became arenas for 'coexistence of emotional worlds', as Ling (2014) states, because emotions are recognized as the 'stuff' connecting human beings to each other and the world around them like an unseen lens colouring all thoughts and actions (Goodwin, Jasper, \& Polletta, 2001, p. 10). Shortly, an 'emotional space' refers to a repository where actions, expressions and reactions are encapsulated. The reflections of various emotions sharing similar experiences and stories in Egypt and Tunisia were shared within the same platform, Tahrir square and Bourguiba Avenue and various other squares of Tunisia, or alternatively, emotional spaces. These spaces hence were transformed from authoritarian spaces into popular spaces where solidarity was demonstrated (Sadiki, 2015, p. 4).

\section{The components of repertoires of emotions in Tunisia and Egypt}

To give some general background, repertoires are 'arrays of means that a group has for making claims of different kinds on different individuals or groups' in Tilly's words (Tilly, 1986: 4). Here, crucial components of a new coordination mechanism depict new repertoires of transnational movements that are coordinated by collective action, brokerage and diffusion (Tilly \& Tarrow, 2007, p. 32). One of the components is collective action which is transnationally coordinated leads to the brokerage of the society triggering mass mobilization. As a result, online activism - the essential factor of the network society - diffuses emotions, ideas and new belief systems across the region. This emotional diffusion through information flows is related to the designation of the politics as well. Thus, these components of repertoires were intertwined in the Arab Spring. There are five components of repertoires of the transnational coordinated mechanism of the Arab Spring to catalyse a transformation through performing interactive reactions of people in public spaces.

\section{Collective action}

The first component of repertoire is collective action. Goffman (in Benford \& Snow, 2000, p. 614) contends that transnational social movements are framed with particular repertoires including various tactics and tools allowing people to identify and locate their movements. Since 'movements are collectively organized actions' (Laraña, Johnston, \& Gusfield, 1994, p. 60), they are defined by collective of emotions, ideas and values of particular groups. The rise of collective consciousness in Egypt was empowered by Tunisia. In this regard, an Egyptian activist described this collective consciousness as realization through strength and courage (Ghafar, 2015, p. 59). For this reason, 'the embodied experience of collective presence heightened such feelings' (Solomon, 2018, p. 949). Hall and Ross (2015, p. 859) explain the translation of emotions into action in light of collective action:

An event that elicits similar strong emotions across individuals, for example, may produce spontaneous public expression, in turn facilitating transmission, social articulation, and further intensification.

Essentially, 'collection of individuals experiencing the same emotion' leads to various identities experiencing a group-level emotion that can be stronger than an individual level emotion (Mercer, 2014 , p. 515). These collective or group-level emotions, ideas and values construct the demands of the people. These demands spread transnationally to influence many groups. In short, 'collective action frames are action-oriented sets of beliefs and meanings that inspire and legitimate the activities and campaigns of social movement organization' (Benford \& Snow, 2000, p. 164).

Yet, it should be taken into account that since emotions are inherently internal, they can be examined and understood through specific sets of representations regarding narratives, gestures including 
diverse ways of communicating and interacting feelings and beliefs (Crawford, 2000). Due to the revealing of emotions through various representations, collective identity emerged in Tunisia and Egypt. Thus, I articulate that collective behaviour is an emotional mechanism that has a reflexive nature in terms of toppling authoritarian systems. As addressed earlier, when the fear barrier was broken down in Tunisia, negative emotions including indignation, fear and anger turned into positive mobilizers that empowered collectivism expanding into Egypt (Jasper, 1998).

Additionally, collective actions within transnational social movements are something that 'reflect on, think about and are aware of (Laraña et al., 1994). From this standpoint, it is witnessed that, people were aware of in the Arab Spring is the repression of authoritarian leaders and the limitation of their liberties and effective political participation. They were also aware of their power to build effective collective action. This triggered people to reflect and to intersect their individual emotions with collective ones, and as a result, raise their voice to make themselves heard despite repression. As a regional bellwether of the Arab Spring, Tunisia demonstrated an enormous response and a highly reflexive emotional action of Tunisian people against the Ben Ali regime. It is evident that they were successful at bridging the gap between these different segments of the population through collective action despite differences amongst various parts and groups of people such as geographical and class discrepancies (Lim, 2013, p. 1). This could be explained by collective action that brings harmony in terms of acting and reflecting emotions, demands and ideas. In short, the central point is that collective action is an instrument which frames both individual emotions, collective emotions, perceptions, values, and common meeting consequences (Benford \& Snow, 2000, p. 614).

\section{Collective identity}

After having mentioned collective action, I look at how collective identity helps people to unite under repression. Della Porta and Diani (2006, p. 21) contend that collective identity is closely linked to the recognition and creation of connectedness bolstered by a pluralism of emotions, ideas and values. Or to put it alternatively, the collection of individuals experiencing same emotions (Mercer, 2014, p. 515) such as aforementioned negative emotions that were transformed into positive ones resulted in huge outrage in Tunisia and Egypt. Through the 'rhythmic entrainment' as Collins (2004, p. 48) points out, emotions were transmitted amongst people under collective action on streets and squares of Tunisia and Egypt that led to the formation of collective identity. Since as Mercer (2014) stresses 'emotion goes with identity', the collective identity becomes a crucial component of the uprisings formed around hope and joy to achieve the resignation of states' leaders in authoritarian states of the Arab world: 'Collective identity refers to a process in which movement participants socially construct a "we" that becomes, in varying degrees with different individuals, part of their own definition of self (Gamson, 1991, p. 45). In this respect, emotions are central to the process 'to make individual agent to move to and impress on the surface of politics' (Fierke, 2013, p. 79).

Collective identity superimposes collective awareness and reflection of the common pursuits embodied by emotions on the transformation track. Bourguiba Avenue and other various squares of Tunisia and Tahrir of Egypt became 'emotional spaces' throughout the Arab Spring for people to raise their voice under the collective identity labelled as 'we'. It is salient to point out that:

The emotional nature of identity and communal belonging is implicit here, because our sense of identity and belonging are constituted by the way we attach and situate ourselves within the social world. (Bleiker \& Hutchison, 2008, p. 124) 
As a result of the emotional attachments of individuals within the collective identity, they are likely to experience emotions to feel for the group, or 'I feel for us' (Yzerbyt, Dumont, Wigboldus, \& Gordijn, 2003). Protests and social movements create and strengthen emotional bonds between adherents in order to establish and empower collective identity (Crossley \& Eyerman, 2005).

Referring back to the last stage of the three-level process, through transformation of emotions, collective emotions and emotional solidarity, the feeling of 'togetherness' emerged sharing the feeling of 'we-ness' formed around 'your problem is my problem, our problem', hence evoking solidarity (Troost et al., 2013, p. 198). In order to increase solidarity and bolster collective identity, upsurges were manifested through language including narratives or particular slogans. This means that rather than personal identities and personal sayings, slogans became prominent elements of collective identities throughout Arab Spring uprisings. The most remarkable slogans were 'the people want to bring down the regime', 'the people demand justice', 'dégage!-go away!', and 'revolution for liberty and dignity' (Sadiki, 2015). Shortly, slogans and symbols reinforced transnational activism (Gamson, 1991, p. 41).

\section{Symbolic politics}

Symbolic politics is the constellation of familiar roots of people to create alternative identities and belief systems which bring about a change (Tarrow, 1998, p. 106). Through the construction of collective identity and collective actions, slogans and manifestations which are shared emotions and values of individuals become symbols of their expression of movements. In this respect, figures of speech in particular, metaphors, comparisons, and analogies have a profound role in encoding emotional expressions (Koschut et al., 2017, p. 484). Thus, an emotion metaphor is a symbolic speech act (Kövecses, 2003). Furthermore, through certain sets of symbols and slogans, emotions as interactive reactions diffused and performed that turned into a mass action at the transnational level.

For example, the Jasmine Revolution, the so-called Tunisian Revolution which became one of the significant symbols of the Arab Spring. Language, slogans and narratives actively construct social relations and self-perceptions (Koschut et al., 2017, p. 497). In addition, Koschut et al. (2017, p. 497) contends that although language produces identities and meanings, they are also infused with emotional attachments and affective orientations' (Koschut et al., 2017, p. 497). The uprisings were based on common symbols and reciprocal elements that formed around emotional attachments. In brief, 'emotions have a big history' suggests the narrative and symbols of humiliation and dignity in the MENA region (Fattah \& Fierke, 2009, p. 70).

Thus, the symbolic interpretation of movements is one part of the process in the contentious movements in order to raise awareness and expand the activities (Keck \& Sikkink, 1998, p. 96). If we look at the main and unique slogan of the Arab Spring, what we perceive regarding symbolic politics within the Arab Spring might be clarified. 'Al-Sha'b yurid isqat al-nizam' means that 'The people want to bring down the regime'. This highlights how powerful and vital the symbols and emotions anger, indignation, the sense of honour and dignity - were in shaping their alternative belief systems and future politics. In the beginning, the revolts in Egypt spread from Tunisia; a collective identity was shared amongst Egyptian and Tunisian people through information flows and common slogans. To illustrate, 'dégage' which was used as one of the key slogans in Tunisia means 'go away' in French; yet this was used in Egypt by the English - and Arab-speaking people as a result of the expansion of symbolic interpretation of politics (Tunis, 2013). In the Arab Spring, 'Symbolism became evident across borders; this connected the otherwise heterogeneous protest movements and led to a reciprocal wave of increasing mobilization within the region' (Rosiny, 2012). 


\section{Network society}

In this section, I explore the other component of repertoires: network society. This buzzword has started to gain prominence within the last decades due to technological advances in the age of globalization. Castells $(2004$, p. 3) states that '[a] network society is a society whose social structure is made of networks powered by microelectronics-based information and communication technologies'. The diffusion of social movements depends upon how dense and diverse the network is (Tilly \& Tarrow, 2007). Dense and diverse networks reinforce and diffuse the movements of people who experienced negative emotions and then positive emotions within a dynamic transnational platform who are newly emerging members of a network society. This can be explained by globalization as well. Throughout the Arab Spring, young people received information and were mobilized by YouTube, Facebook and Twitter to post images of police brutality on the various social networking media and to celebrate their victory within network society that they built (Moghadam, 2013, p. 9). These various elements of the network society translated reactions people expressed as a response to oppression, for example, police brutality in order to organize assemblages.

As the most crucial element of the network society, various media platforms played a great role in the overthrow of Ben Ali and Mubarak such as through digital media, particularly social media like Facebook and Twitter (Allagui \& Kuebler, 2011, p. 1436). This is a unique characteristic of the Arab Spring, therefore, I can single out how the 2010-2011 uprisings were galvanized through a more networked society in comparison with the Gafsa and Mahalla uprisings in 2008. Although they are perceived as initial and nucleus steps to topple regimes, network society and media repertoires were not used during these earlier uprisings.

The Internet allowed movements to impact mass media and spread emotions and uncensored messages transnationally (Della Porta et al., 2006, p. 93). The Internet became the instrument which favoured Arab societies' polycentric and transnational movements across the region (Della Porta et al., 2006, p. 93). Facebook played an essential role as a mobilizing instrument that bolstered collective action in the 2011 uprisings. Whereas in 2008, in Tunisia, there were only 28,000 Facebook users at the time of Gafsa uprisings (Tufekci, 2011), in 2011 there were around 1,900,000 (Maritz, 2011). In Egypt, which had the highest number of Facebook users in MENA in 2011, there were around 4,880,000 Facebook users (Maritz, 2011). Having used Facebook, mobile phones, YouTube, or just word-of-mouth, a number of people - computer literate and analphabetic alike - gathered in the streets, protested, and some eventually died (Tufekci, 2011). Bowles (2006, p. 1570) contends that these networks which create a space, territories for well-developed interaction and strong reciprocity rely upon a sharing behaviour and emotions. The bold point is that the networking reinforced the solidarity among members of networks challenged authoritarian leaders, their online censors, and the police abuses (Allagui \& Kuebler, 2011, p. 1436).

Furthermore, a hybrid network system promoted high transnational information flow across the MENA. As one demonstrator from Cairo stated, 'We use Facebook to schedule the protests, Twitter to coordinate, and YouTube to tell the world' (Chebib \& Sohail, 2011, p. 139). The utilization of technology and social media accompanied by wide popular participation demonstrate the level of knowledge and social awareness which most outsiders assumed did not even exist in the Arab World (Pace \& Cavatorta, 2012, p. 132).

As Lim (2013, p. 10) contends, the mobilization of collective action in the Arab Spring was not only conducted through Facebook or Twitter but also other media instruments. Besides social media - Facebook and Twitter - big media (TV channels such as Al Jazeera) and small media (cell phones, laptops) played crucial roles (Lim, 2013, p. 9). These three types of media build a hybrid 
network system (Lim, 2013, p. 9). Thus, people who were not on the streets to revolt were able to participate through hybrid media as active supporters of upsurges on the streets.

In the aftermath of the self-immolation of Bouazizi at $11.30 \mathrm{am}$, initially cell phones as small media spread the news to his relatives and friends. They also let independent journalists know about the incident to give information on SBZone Fm Radio (Lim, 2013, p. 11). In the meantime, some people also called the Al Jazeera Mubashar Channel to help spread this news across the region (Lim, 2013, p. 11). This led to thousands of people spreading the news through Facebook since people started to copy $\mathrm{Al}$ Jazeera news.

With respect to the Egyptian uprisings, one of the first activists groups was the April 6th Movement which had a focal role of network society of Egypt. This was established to support workers in El-Mahalla El-Kubra in 2008. Yet, this group expanded its supporters to revolt against Mubarak right after Khaleed Saeed was brutally killed by the police. Their website was one of the leading networking mechanisms to gather people. Besides, Facebook, Twitter and other various social media were utilized to organize people to create a mass movement through the founders and supporters of April 6th Movement. In the meantime one of the founders of this movement group, Asmaa Mahfouz, shared a video on YouTube in which basically said 'Don't be afraid [of] the government' (PBS, n.d.). This call galvanized people to emotionally come together and become a 'we' despite the repressive Mubarak regime. Yet censorship continued during the Arab Spring in Egypt. Despite censorship of the Internet by the Egyptian government, the network society of Egypt through well-constructed collective action and collective identity managed to communicate even on 27 January 2011.

\section{Information politics}

Information politics has been one of the crucial components of the transnational social movements which catalyse the transformation process of negative emotions. With respect to the translation of emotions into action, emotions were strategically utilized by activists, which was the basis for strategic thought that generated transnational information flows through network society (Goodwin et al., 2001, p. 9). As introduced by Keck and Sikkink (1998, p. 2): information flows of transnational activism were constructed by the 'relevant actors working internationally on an issue, who are bound together by shared values, a common discourse, and a dense exchange of information and services'.

In addition, shared norms and emotions play a crucial role to create the process of regional integration (Keck \& Sikkink, 1998, p. 90), as evidenced by the domino effect of regional revolts in the Arab Spring. Castells (2004, p. 14) stresses that since politics mainly depends upon the public space of socialized communication, the political process is generated under the circumstances of the culture of real virtuality that is a system in which reality itself (that is, people's material/symbolic existence) is entirely captured. Therefore, in the case of the Arab Spring, social communication and networking as a result of being a part of real virtuality were the most significant factors for toppling the regimes and shaping politics in Tunisia and Egypt.

Furthermore, Castells (2004, p. 17) argues that information flows through networking and communication within the transnational movements render the shifting power from the state to the network society. Transnationalism became obvious in the whole Arab region through new links amongst new actors such as civil society or other agencies; as a result, social movements linked in a more efficient manner by an increase in dialogue, emotion and information exchange (Keck \& Sikkink, 1998, p. 94). Information flows provide not only facts but also testimonies such as stories told by people who are affected (Keck \& Sikkink, 1998, p. 95). 


\section{Conclusion}

This article has argued why and how the Arab Spring started and expanded into the region in light of key motives which pushed people to overthrow Ben Ali and Mubarak. In this article, emotions are defined as interactive reactions that are mutually formed by individual level and collective level experiences and expressions. In the context of the Arab Spring, within transnational protests, these emotions or alternatively interactive reactions mainly derived from reactions regarding what people experienced under oppressive political orders in Tunisia and Egypt leading them to express their responses out-loud in emotional spaces. Therefore, emotions have been addressed as a catalyst whose mechanism of action is performed by repertoires. The three-level process has been dealt with in detail in order to demonstrate the three levels of intersection of individual emotions with collective emotions. In the first level, through emergence of negative emotions - indignation, fear and anger-; firstly Tunisian people reacted against Bouzazizi's self-immolation that was caused by oppression, injustice and despotism. The reaction against this shock led emotions to merge on the same platform. Consequently, positive emotions emerged in the second level that formed joy and hope on the streets of Tunisia and Egypt. This positive atmosphere finally resulted in the outrage and resistance centred upon solidarity and certain symbols to fight in order to overthrow the leaders of states.

In order to examine emotions throughout the three-level analysis, this article has synthesized two literatures: IR and social movements studies in light of collective-level emotions. This article makes an original contribution to various debates in IR and social movements literatures. Firstly, it offers insights to these two literatures in light of emotions' roles as catalytic mechanism in mobilizations in Tunisia and Egypt by speaking broader than discussions on emotions and elite decision-making or emotions and state behaviour. Secondly, through incorporating diverse components of repertoires in order to explain performances of interactive reactions in the Arab Spring, this article distinctively expands the study of the Arab Spring. In this regard, collective action and collective identity have been analysed as the construction of collective emotions during the uprisings. The outrage was spilled over through network society and information politics formed around symbolic politics surrounded by sets of slogans and symbols.

\section{Acknowledgements}

I would like to thank anonymous reviewers for their constructive and helpful comments.

\section{Notes on contributor}

Efser Rana Coşkun is a PhD Candidate and Teaching Assistant in the Department of International Relations, Bilkent University, Turkey. She holds an MSc degree in International Development from University of Bristol, United Kingdom, and BSc in Global and International Affairs from Middle East Technical University in Turkey and Binghamton University, USA. Her research interests cover the fields of theories of International Relations with a particular focus on non-Western perspectives, emotions, resilience, the interplay between development studies and social movements, and humanitarianism particularly in terms of Turkey's humanitarian agency in Somalia and Syrian refugee crisis.

\section{Disclosure statement}

No potential conflict of interest was reported by the author. 


\section{ORCID}

Efser Rana Coşkun (D) http://orcid.org/0000-0002-3703-8550

\section{References}

Abdalla, N. (2016). Youth movements in the Egyptian transformation: Strategies and repertoires of political participation. Mediterranean Politics, 21(1), 44-63.

Agathangelou, A. M., \& Soguk, N. (2011). Rocking the Kasbah: Insurrectional politics, the "Arab streets", and global revolution in the 21st century. Globalizations, 8(5), 551-558.

Ahmed, S. (2004). The cultural politics of emotion. New York, NY: Routledge.

Ajami, F. (2011, February 26). How the Arabs turned shame into liberty. New York Times. Retrieved from http://www.nytimes.com/2011/02/27/opinion/27ajami.html?pagewanted_all\&_r_0

Al Jazeera. (2011). The Arab Awakening. Retrieved from http://english.aljazeera.net/programmes/general/ 2011/04/20114483425914466.html

Alexander, C. (2011, January 3). Tunisia's protest wave and what it means for Ben Ali. Foreign Policy. Retrieved from http://mideast.foreignpolicy.com/posts/2011/01/02/tunisia_s_protest_wave_where_it_comes_from_ and_what_it_means_for_ben_ali

Allagui, I., \& Kuebler, J. (2011). The Arab Spring and the role of ICTs: Editorial introduction. International Journal of Communication, 5, 1435-1442.

Aminzade, R. R., \& McAdam, D. (2001). Emotions and contentious politics. In R. R. Aminzade, J. A. Goldstone, D. McAdam, E. J. Perry, W. H. Sewell Jr, S. Tarrow, \& C. Tilly (Eds.), Silence and voice in the study of contentious politics (pp. 14-50). New York, NY: Cambridge University Press.

Anis. (2012, December 31). Dorénavant, on n'a plus peur, Anis Ibn Baddouda around the world. Retrieved from http:// anisb.wordpress.com/2010/12/30/dorenavant-on-na-plus-peur-

Axford, B. (2011). Talk about a revolution: Social media and the MENA uprisings. Globalizations, 8(5), 681686.

Bayat, A. (2013). Life as politics. Stanford, CA: Stanford University Press.

Bellin, E. (2012). Reconsidering the robustness of authoritarianism in the Middle East: Lessons from the Arab Spring. Comparative Politics, 44(2), 127-149.

Benford, R. D., \& Snow, D. A. (2000). Framing processes and social movements: An overview and Assessment. Annual Review of Sociology, 26, 611-639.

Bially Mattern, J. (2011). A practice theory of emotions for International Relations. In E. Adler, \& V. Pouliot (Eds.), International practices (pp. 63-86). Cambridge: Cambridge University Press.

Bleiker, R., \& Hutchison, E. (2008). Fear no more: Emotions in world politics. Review of International Studies, 34(1), 115-135.

Bowles, S. (2006). Group competition, reproductive leveling, and the evolution of human altruism. Science, 314 (5805), 1569-1572.

Calhoun, C. (2001). Putting emotions in their places. In J. Goodwin, J. M. Jasper, \& F. Polletta (Eds.), Passionate politics emotions and social movements (pp. 45-54). Chicago, IL: The University of Chicago Press.

Carreon, M. E., \& Moghadam, V. M. (2015). Resistance is fertile: Revisiting maternalist frames across women's mobilization. Women's Studies International Forum, 51, 19-30. doi:10.1016/j.wsif.2015.04.002

Castells, M. (2004). Informationalism, networks, and the network society: A theoretical blueprint. In M. Castells (Ed.), The network society: A cross-cultural perspective (pp. 3-45). Massachusetts: Edward Elgar.

Castells, M. (2012). Networks of outrage and hope: Social movements in the internet age. Cambridge: Polity Press.

Chebib, N., \& Sohail, R. M. (2011). The reasons social media contributed to the 2011 Egyptian Revolution. International Journal of Business Research and Management, 2(3), 139-162.

Clore, G. L., \& Huntsinger, J. R. (2009). How the object of affect guides its impact. Emotion Review, 1(1), 39-54.

Collins, R. (1990). Stratification, emotional energy, and the Transient emotions. In T. D. Kemper (Ed.), Research agendas in the sociology of emotions (pp. 27-67). Albany, NY: SUNY Press.

Collins, R. (2004). Interaction ritual chains. Princeton, NJ: Princeton University Press.

Crawford, N. (2000). The passion of world politics: Propositions on emotions and emotional relationships. International Security, 24(4), 116-156. 
Crawford, N. (2014). Institutionalizing passion in world politics: Fear and empathy. International Theory, 6(3), 535-557.

Crossley, N., \& Eyerman, R. (2005). How social movements move: Emotions and social movements. In H. Flam, \& D. King (Eds.), Emotions and social movements (pp. 42-56). London: Routledge.

Dajani, N. (2012). Technology cannot a revolution make: Nas-book not Facebook. Arab Media and Society. Retrieved from http://www.arabmediasociety.com/?article $=782$

De Sousa, R. (1987). The rationality of emotion. Cambridge: MIT.

Della Porta, D., Andretta, M., Mosca, L., \& Reiter, H. (2006). Globalization from below: Transnational activists and protest networks. Minnesota: University of Minnesota Press.

Della Porta, D., \& Diani, M. (2006). Social movements an introduction. (2nd ed.). Oxford: Wiley-Blackwell. Edkins, J. (2003). Trauma and the memory of politics. Cambridge: Cambridge University Press.

El-Shobaki, A. (2011, January 17). Egypt is not Tunisia. Egypt Independent. Retrieved from http://www. egyptindependent.com/opinion/egypt-not-tunisia

Elster, J. (1999). Alchemies of the Mind: Rationality and the emotions. Cambridge: Cambridge University Press.

Eznack, L. (2011). Crises as signals of strength: The significance of affect in close allies' relationships. Security Studies, 20(2), 238-265.

Eznack, L. (2013). The mood was grave: Affective dispositions and states' anger-related behaviour. Contemporary Security Policy, 34(3), 552-580.

Fattah, K., \& Fierke, K. M. (2009). A clash of emotions: The politics of humiliation and political violence in the Middle East. European Journal of International Relations, 15(1), 67-93.

Fierke, K. M. (2013). Political self-sacrifice: Agency, body and emotion in international relations. cambridge: cambridge university press.

Freedom House. (2013). Tunisia. Retrieved from http://www.freedomhouse.org/report/freedom-world/2013/ tunisia

Frijda, N. H. (1986). The emotions. Cambridge: Cambridge University Press.

Gamson, W. A. (1991). Commitment and agency in social movements. Sociological Forum, 6(1), 27-50.

Ghafar, A. A. (2015). The moment the barrier of fear broke down. In A. Al-Saleh (Ed.), Voices of the Arab Spring (pp. 55-59). New York, NY: Columbia University Press.

Goodwin, J., \& Jasper, J. M. (2006). Emotions and social movements. In J. E. Stets, \& J. H. Turner (Eds.), Handbook of the sociology of emotions (pp. 611-635). New York, NY: Springer.

Goodwin, J., Jasper, J. M., \& Polletta, F. (2000). The return of the repressed: The fall and rise of emotions in social movement theory. Mobilization: An International Journal, 5(1), 65-83.

Goodwin, J., Jasper, J. M., \& Polletta, F. (2001). Passionate politics emotions and social movements. Chicago, IL: The University of Chicago Press.

Goodwin, J., Jasper, J. M., \& Polletta, F. (2004). Emotional dimensions of social movements. In D. A. Snow, S. A. Soule, \& H. Kriesi (Eds.), The Blackwell companion to social movements (pp. 413-432). Oxford: Blackwell.

Goodwin, J., \& Pfaff, S. (2001). Emotion work in high-risk social movements: Managing fear in the U.S. and East German civil rights movements. In J. Goodwin, J. M. Jasper, \& F. Polletta (Eds.), Passionate politics emotions and social movements (pp. 282-302). Chicago, IL: The University of Chicago Press.

Guardian. (2011, February 1). Alexandria: 'Mubarak, today is your last day'. Retrieved from https://www. theguardian.com/world/2011/feb/01/mubarak-last-day

Hale, H. E. (2013). Regime change cascades: What we have learned from the 1848 revolutions and the 2011 Arab uprisings. Annual Review of Political Science, 16, 331-353.

Hall, T. (2016). Emotional diplomacy: Official emotion on the international stage. Ithaca: Cornell University Press.

Hall, T., \& Ross, A. A. G. (2015). Affective politics after 9/11. International Organization, 69(4), 847-879.

Hardin, R. (1995). One for all: The logic of group conflict. Princeton, NJ: Princeton University Press.

Hill, C. (2003). The changing politics of foreign policy. Houndmills: Palgrave.

Hirshleifer, J. (1993). The affections and the passions: Their economic logic. Rationality and Society, 5(2), 185202.

Hollis, R. (2012). No friend of democratization: Europe's role in the genesis of the 'Arab Spring'. International Affairs, 88(1), 81-94.

Huber, D., \& Kamel, L. (2015). Arab Spring: The role of the peripheries. Mediterranean Politics, 20(2), 127141. 
Hutchison, E. (2016). Affective communities in world politics. Cambridge: Cambridge University Press.

Hutchison, E., \& Bleiker, R. (2014). Theorizing emotions in world politics. International Theory, 6(3), 491-514. Hutto, D. (2012). Truly enactive emotion. Emotion Review, 4(2), 176-181.

Jasper, J. M. (1997). The art of moral protest culture, biography, and creativity in social movements. Chicago, IL: The University of Chicago Press.

Jasper, J. M. (1998). The emotions of protest: Affective and reactive emotions in and around social movements. Sociological Forum, 13, 397-424.

Jervis, R. (1976). Perception and misperception in international politics. Princeton, NJ: Princeton University Press.

Jervis, R., Lebow, R. N., \& Stein, J. G. (1985). Psychology and deterrence. Baltimore: John Hopkins University Press.

Keck, M. E., \& Sikkink, K. (1998). Activists beyond borders: Advocacy networks in international politics. Ithaca, NY: Cornell University Press.

Kemper, T. (2001). A structural approach to social movement emotions. In J. Goodwin, J. M. Jasper, \& F. Polletta (Eds.), Passionate politics emotions and social movements (pp. 58-73). Chicago, IL: The University of Chicago Press.

Khalil, K. (2011). Messages from Tahrir: Signs from Egypt's revolution. Cairo: American University in Cairo Press.

Khondker, H. H. (2011). Role of the new media in the Arab Spring. Globalizations, 8(5), 675-679.

Kleres, J., \& Wettergren, A. (2017). Fear, hope, anger and guilt in climate activism. Social Movements Studies, 16(5), 507-519.

Koschut, S. (2014). Regional order and peaceful change: Security communities as a via media in international relations theory. Cooperation and Conflict, 49(4), 519-535.

Koschut, S. (2017a). No sympathy for the devil: Emotions and the social construction of the democratic peace. Cooperation and Conflict. doi:10.1177/0010836717737570

Koschut, S. (2017b). The power of (emotion) words: On the importance of emotions for social constructivist discourse analysis in IR. Journal of International Relations and Development. doi:10.1057/s41268-017-0086-0

Koschut, S., Hall, T. H., Wolf, R., Solomon, T., Hutchison, E., \& Bleiker, R. (2017). Discourse and emotions in international relations. International Studies Review, 19(3), 481-508.

Kövecses, Z. (2003). Metaphor and emotion: Language, culture, and the body in human feeling. Cambridge: Cambridge University Press.

Laraña, E., Johnston, H., \& Gusfield, J. R. (1994). New social movements: From ideology to identity. Philadelphia: Temple University Press.

Larson, D. W. (1985). Origins of containment: A psychological explanation. Princeton, NJ: Princeton University Press.

Lasas, A. (2011). Bringing emotions into understanding revolutions. United Nations University. Retrieved from http://unu.edu/publications/articles/the-role-of-emotions-in-politics.html

Lim, M. (2013). Framing Bouazizi: 'white lies', hybrid network, and collective/connective action in the 2010-11 Tunisian uprising. Journalism: Theory, Practice \& Criticism, 14(7), 921-941.

Ling, L. H. M. (2014). Decolonizing the international: Towards multiple emotional worlds. International Theory, 6(3), 579-583.

Linklater, A. (2014). Anger and world politics: How collective emotions shift over time. International Theory, 6 (3), 574-578.

Lynch, M. (2012). The Arab uprisings: The unfinished revolutions of the New Middle East. New York, NY: Public Affairs.

Lynch, M. (2014). Media, old and new. In M. Lynch (Ed.), The Arab uprisings explained: New contentious politics in the Middle East (pp. 93-109). New York, NY: Columbia University Press.

Maritz, J. (2011, January 19). Top African countries on Facebook, how we made it in Africa. Retrieved from http://www.howwemadeitinafrica.com/top-10-africancountries-on-facebook/6980/

Massumi, B. (2002). Parables for the virtual: Movement, affect, sensation. Durham, NC: Duke University Press.

McAdam, D. (1982). Political process and the development of black insurgency. Chicago, IL: University of Chicago Press.

Mercer, J. (2006). Human nature and the first image: Emotion in international politics. Journal of International Relations and Development, 9, 288-303. 
Mercer, J. (2010). Emotional beliefs. International Organization, 64(1), 1-31.

Mercer, J. (2014). Feeling like a state: Social emotion and identity. International Theory, 6(3), 515-535.

Moghadam, V. M. (2013). Globalization and social movements Islamism, feminism, and the global justice movement (2nd ed). Lanham, MD: Rowman \& Littlefield.

Nussbaum, M. C. (2001). Upheavals of thought: The intelligence of emotions. Cambridge: Cambridge University Press.

Pace, M., \& Bilgiç, A. (2017). Trauma, emotions, and memory in world politics: The case of the European Union's foreign policy in the Middle East Conflict. Political Psychology. doi:10.1111/pops.12459

Pace, M., \& Cavatorta, F. (2012). The Arab uprisings in theoretical perspective - An introduction. Mediterranean Politics, 17(2), 125-138.

Patel, D., Valerie, B., \& Sharon, W. (2014). Diffusion and demonstration. In M. Lynch (Ed.), The Arab uprisings explained: New contentious politics in the Middle East (pp. 57-74). New York, NY: Columbia University Press.

PBS. (n.d.). Countdown to the Jan.25 revolution. Retrieved from http://www.pbs.org/wgbh/pages/frontline/ revolution-in-cairo/inside-april6-movement/

Pearlman, W. (2013). Emotions and the microfoundations of the Arab uprisings. Perspectives on Politics, 11(2), 387-409.

Rosiny, S. (2012). The Arab Spring: Triggers, dynamics and prospects. German Institute of Global and Area Studies: Hamburg.

Ross, A. A. G. (2014). Mixed emotions: Beyond fear and hatred in international conflict. Chicago, IL: University of Chicago Press.

Ryan, C. (2014). Inter-Arab relations and the regional system. In M. Lynch (Ed.), The Arab uprisings explained: New contentious politics in the Middle East (pp. 110-123). New York, NY: Columbia University Press.

Sadiki, L. (Ed.) (2015). Routledge handbook of the Arab Spring: Rethinking democratization. New York, NY: Routledge.

Sassen, S. (2011). The global street: Making the political. Globalizations, 8(5), 573-579.

Shaw, D. (2011, December 26). The big stories affecting you in 2011: Arab Spring. BBC News. Retrieved from http://www.bbc.co.uk/news/world-middle-east-16275176

Siddique, H., Paul, O., \& Adam, G. (2011, January 25). Protests in Egypt and unrest in the Middle East - as it happened. Guardian Newsblog. Retrieved from http://www.theguardian.com/global/blog/2011/jan/25/ middleeast-tunisia

Soguk, N. (2015). Insurrectional politics: Theories and practices of Contemporary Insurrections. Globalizations, 12(6), 829-833.

Solomon, T. (2018). Ontological Security, circulations of affect and the Arab Spring. Journal of International Relations and Development, 21, 934-958.

Tarrow, S. (1998). Power in movement. Cambridge: Cambridge University Press.

Thrift, N. (2004). Intensities of feeling: Towards a spatial politics of affect. Geogrfiska Annaler: Series B, 86(1), $57-78$.

Tilly, C. (1978). From mobilization to revolution. Reading, MA: Addison-Wesley.

Tilly, C. (1986). The contentious French. Cambridge: Harvard University Press.

Tilly, C., \& Tarrow, S. (2007). Contentious politics. Oxford: Oxford University Press.

Troost, D., Stekelenburg, J., \& Klandermans, B. (2013). Emotions of protest. In N. Demertzis (Ed.), Emotions in politics: The affect dimension in political Tension (pp. 186-203). New York, NY: Palgrave Macmillan.

Tufekci, Z. (2011, August 30). New media and the people powered uprisings. Technology Review. Retrieved from http://www.technologyreview.com/view/425280/newmedia-and-the-people-powered-uprisings/

Tufekci, Z., \& Wilson, C. (2012). Social media and the decision to participate in political protest: Observations from Tahrir square. Journal of Communication, 62(2), 363-379.

Tunis, S. J. (2013, June 21). Children of the revolution. The Economist. Retrieved from http://www.economist. com/blogs/pomegranate/2013/06/arab-spring

Walsh, E. J. (1981). Resource mobilization and citizen protest in Communities around three Mile Island. Social Problems, 29, 1-21.

Weyland, K. (2012). The Arab Spring: Why the surprising similarities with the revolutionary wave of 1848 ?. Perspectives on Politics, 10(4), 917-934.

Yzerbyt, V., Dumont, M., Wigboldus, D., \& Gordijn, E. (2003). I feel for us: The impact of categorization and identification on emotions and action tendencies. British Journal of Social Psychology, 42(4), 533-549. 